\title{
EFFECT OF DISINFECTANTS, FLOCK PHYSIOLOGICAL STATUS, SEASON AND STORAGE PERIOD OF BROILER BREEDER EGGS ON FIELD HATCHABILITY AND HATCHERY OPERATION QUALITY UNDER NEW-SALHEYA CITY SITUATION
}

\author{
A.M. Hanafy, E.G. Ahmed, A.M. Abdel-Ghany and M.H. Nashaat
}

Animal Production Department, College of Agriculture, Suez Canal University, Ismailia, Egypt

\section{SUMMARY}

The present field study was conducted to determine the effects of: 1) 3 types of disinfectants (i.e. Biosentry-904, Egg-Washer-Pro and Virkon-S); 2) storage duration (i.e. from 1 through 6 days); 3) flock production stage (before peak, from 28 to34 weeks and at peak production stages, from 35 to 45 weeks of flock age) and 4) season (i.e. Spring and Winter) on hatchery operation quality of a Cobb broiler breeder flock. Data analyzed was comprised of about five hundred and seventy four thousand (574,000), eggs.

Traits studied were percentages of on \%overall (Trolley) hatchability along with fertility, clear (infertile) eggs, hatchability (\%hatched chicks), \%eggs losses (exploded), \% Abnormal embryonic positions, \%Omphalitis, \%pipped eggs in addition to \% early and late embryonic mortality of egg tray. The superiority in most traits has been related, generally, with Egg-Washer-Pro and Biosentry-904, followed in most traits by Virkon-S and eventually the control group. Storage period had high significant effects $(P \leq 0.001$ or $P \leq 0.0001)$ on \% overall (Trolley) hatchability; \% apparent fertility; \%infertility; hatched chicks, \%late embryonic mortality and \% pipped eggs traits. Results revealed generally that most hatchery measurements can be improved by storing fertile eggs for two to four days before being set in incubators. Most characteristics of incubation measurements varied significantly with flock production status (peak effect). All studied traits varied insignificantly with season effect, but \% pipped eggs $(P \leq 0.01)$.

Keywords: disinfectants, storage period, physiological status, hatchability, hatchery operation quality, Broiler breeder.

\section{INTRODUCTION}

Hygiene is an important aspect and major concern to poultry industry-, particularly in the hatcheries. Poor hygiene leads to reduced hatching rates and poor chick quality (Brake and Sheldon, 1990; Fueng-Lin et al., 1996). In fact, a strong bacterial penetration through the egg shell will affect several aspects in hatching quality, in many ways such as early embryonic mortality, egg yolk infection, day-old-chick mortality before hatching and heterogeneity of the chicks during the first week of age. With the progressive development of the poultry industry, it is feasible that sanitizing hatching eggs should start as fast as possible after collection, the standpoint that is essential to reduce the risks and to control the number of microorganisms on shell surface by an adequate method and/or compound (Gheith et al., 2005; Gehan et al., 2009) is important. It is therefore evident that maximum sanitary standards must be practiced in hatcheries in order to minimize the soiling of eggs and to destroy the detrimental microorganisms before they enter into the egg (Chima et al., 2012) which ascertain the importance of establishing a pathogen reduction program within the entire poultry production industry.

Impact of disinfectants as a hatchery operation is to onslaught salmonella and other microorganism that affect the qualities of hatching chicks, where salmonellae may proliferate as the embryo develops, divide up, allocate at hatching and spread in the hatching machine (Cason et al., 1994). Organism type and the immediacy of treatment affected significantly the efficacy and success of disinfection (Cox and Bailey, 1991). Also hatcheries play a role as the check point in avoiding infection in production cycle. Leaving the floor eggs and strict hygiene of the nests at the farm is necessary to reduce the bacterial load.

Disinfecting hatching eggs is a critical control point in the poultry hatchery where facing a wide variety of pathogen such as bacteria, fungi, viruses and protozoa. All disinfectants used in the hatchery should be highly germicidal, nontoxic, non-corroding and non staining, soluble in water, capable of penetrating materials and surfaces, unassociated with pungent odors and readily available and inexpensive (North, 1984; Scott and Swetnam, 1993a). Sanitizers may be grouped according to their base ingredient. The major families of 
disinfectants are the following: halogens (chlorine, iodine), aldehydes, quaternary ammonium compounds (QACs), phenol and derived and oxidizing agents (Samberg and Meroz, 1995). Each family has its own characteristics and their activity spectrum is relatively specific (Scott and Swetnam, 1993b). Hydrogen peroxide is easily destroyed after use and poses minimal safety problems. It has been used as sanitizers for reduction of total bacteria and salmonella in hatching cabinet in liquid or spray forms, apparently without adversely affecting hatching potential (Mauldin and Wilson, 1988; Sheldon and Brake, 1991). However, Virkon-S was essentially ineffective against the inoculated microorganisms (Scott and Swetnam, 1993b). QACs globally demonstrate and were effective in $95 \%$ reduction of the major hazard, salmonella, incubated to hatchery eggs (Cox et al., 2007).

All disinfectants are less effective in the presence of organic material present on the shell. Organic matter interferes with the action of disinfectants by coating the pathogen and preventing contact with the disinfectant and this effect may vary with different groups of disinfectant (Russell et al., 1992). Information on such variations is required to select the most appropriate disinfectant for application in the hatchery. Spraying hatching eggs by EggWasher-Pro disinfectant which includes digestive enzymes capable of digesting the organic matter found on the surface of egg shell and depriving the microorganism from the media it needs during the process of penetration.

The hatchability of eggs set is dependent not only on bio-security management, but also on hatchery-related factors, such as storage periods or incubation programs (King'ori, 2011). Also the age of the flock and number of storage days are typically included in the analysis and optimization of hatchery results, but very often, insufficient attention is paid to the quality of the hatching eggs. Many researchers recorded that prolonged storage time caused a decrease in the hatchability and chick quality of broiler breeder eggs (Alsobayel et al., 2013 and Khan et al., 2013; 2014), guinea fowl eggs (Moreki and Mack, 2013) and quail eggs (Romao et al., 2008; Othman et al., 2014). The hatchability was significantly reduced when eggs were stored for 8 days compared to 6 days or less. While external quality of hatching eggs is usually considered, there is much debate regarding internal quality control on a regular basis. Thus, every effort should be taken to ensure that hatching eggs are not stored for more than 6 days.

Therefore, the present study was conducted under field conditions, to determine the effects of three types of disinfectants (Quaternary ammonium, Enzymes and Oxidizing agents), storage duration (six periods), season (spring and winter) and flock production status (before and at peak) on the hatchability and hatchery operation quality of the Cobb broiler breeder under New-Salheya City Situations.

\section{MATERIALS AND METHODS}

The controlled experimental work was carried out during the period from February to June 2011, in Poultry Investment Misr Company in New Salheya City, Sharqia Governorate, Egypt.

About five hundred and seventy four thousand eggs produced from a commercial broiler breeders flock, Cobb strain, were used in this field study. Fertile eggs were collected for 17 weeks during the period from 28 to 45 week of age. Eggs collected from 28 to 34 week of flock age were considered as before peak while from 35 to 45 weeks were estimated as at peak production. Daily on-farm collected eggs were transported to the hatchery to be stored or incubated according to production plans. The storage periods for eggs till incubation were from 1 - 6 days under conditions of $18{ }^{\circ} \mathrm{C}$ and $75 \%$ relative humidity. Before incubation, suitable eggs were selected and arranged in the trays fitting inside the trolley. These trollies were moved to incubation machines or to refrigerators according to hatchery routines.

\section{Preparation of disinfectants and eggs treatments:}

In the receiving room, selected eggs were sprayed with one disinfectant per one trolley and the $4^{\text {th }}$ trolley has been left unsprayed (control). The first trolley was sprayed by, Biosentry-904, (Quaternary ammonium compound). The disinfectant mode of action is cytolyses damage to microorganism cells. It is prepared by dissolving $4 \mathrm{ml}$ Biosentry-904 per 1 liter of tap water.The second trolley was spraying by EggWasher-Pro (enzymatic) which includes digestive enzymes capable of digesting the organic matter found on the surface of egg shell and depriving the microorganism from the media it needs during the process of penetration. The solution of this enzymatic disinfectant is prepared by mixing $3 \mathrm{ml}$ Egg-Washer-Pro per 1 liter tap water. The third trolley was sprayed with Virkon-S (Oxidizing agent). This group of disinfectants releases nascent or emerging Oxygen atom which destroys the enzyme and ribosome system of the microorganisms. It is prepared by liquefying $5 \mathrm{gm}$ Virkon-S per 1 liter of tap water. About 2 hours post-spraying, eggs were allowed to dry for avoiding chemicals composition changes inside the hatchery.

The hatchery machines and eggs management 
The 12 cabinet hatchery machines are comprised from units of smaller Petersime setter (Belgium) with a capacity of 115,200 hatching eggs divided into six patches. Each patch (19,200 eggs) was comprised of four trolleys with a trolley capacity of 4800 eggs arranged in 32 trays, each tray containing 150 eggs.

Three trays were taken from each trolley as sampled during incubation and at hatching. One tray was chosen as a sample from the uppermost/topmost of trolley while the second sample (tray) was from the core/middle and the third sample was from the floor/bottom. The whole sample is consisted from 3 trays/treated equaling 1,800 eggs per patch. During the whole studying period, 17 weeks, a total of 30 patches were sampled. Consequently, this totaled 54,000 eggs during the whole studying period.

The environmental conditions inside the incubator were $37.7{ }^{\circ} \mathrm{C}$ and $60 \%$ relative humidity. Due to rationality considerations related to commercial practices, eggs were candled not before the $7^{\text {th }}$ day of incubation period. On the $18^{\text {th }}$ day of incubation, the eggs were transferred to the hatcher in plastic-basketlike-trays and incubated at $37.2{ }^{\circ} \mathrm{C}$ and $70 \%$ relative humidity for 3 days.

\section{Traits studied:}

At hatching day, the healthy flourishing alive chicks in each tray treatment were counted (numbers of healthy hatched chicks). Un-hatched eggs at all candled stages opened and the case of embryo death was determined by visual inspection (numbers of early dead, 1-7 days; late dead, 8-21 days). Eggs that did not show early embryonic death were counted as infertile. Chicks that couldn't emerge from the egg for any reason were considered pipped chicks.

Data collected all over the period of the study on \%overall (Trolley) hatchability, number of fertile, number of \%infertile (clear), number of hatched chicks per sample, number of egg losses, Abnormal embryonic positions, number of Omphalitis cases, number of pipped eggs, number of early and late embryonic mortality of each egg tray.

The percentages of hatchery trait measurements were calculated according to the following equations.

$\%$ apparent fertility $=($ numbers of fertility $/ 150$ eggs $) * 100, \%$ infertility $($ clear $\%)=($ numbers of infertile eggs / 150 eggs) * 100, Hatched chicks\% $=($ numbers of hatched chicks $/ 150$ eggs $) * 100$; and (numbers of hatched chicks/ numbers of fertility), Egg losses \% = (numbers of eggs losses $/ 150$ eggs $) * 100$, Abnormal embryonic positions $\%=$ (numbers of abnormal embryonic positions / 150 eggs) $* 100$, Omphalitis $\%=$ (numbers of Omphalitis cases / 150 eggs) * 100, Pipped eggs $\%=($ pipped Eggs $/ 150$ eggs $) * 100$, Early embryonic mortality $\%=$ (numbers of early embryonic mortality at 7 days candling / 150 eggs) * 100. Late embryonic mortality \% = (numbers of late mortality embryonic / 150 eggs) $* 100, \%$ Patch hatchability $=\{$ numbers of hatched chicks / total number of eggs in a trolley (4800 eggs) $\} * 100$ to be used as contemporary standard.

\section{Statistical Analysis:}

Data of \%overall hatchability, and on\% apparent fertility, \%infertility (clear), \% hatchability, \% eggs losses, \%Abnormal embryonic positions, \% Omphalitis, \% pipped eggs, \% early and \%late embryonic mortality of egg tray were analyzed using SAS 9.3 (2003). Values were transformed to arcsine before analysis and recoded back to normal values to get the tabulated means. The linear fixed model adopted for the analysis comprised the effects types of disinfectants, storage period, peak of egg production and season status. This output of statistical analysis was presented in Table (1). This output reveals that interactions were mostly non-significant and it is statistically acceptable to discuss the main effects of factors involved in the model.

\section{RESULTS}

\section{Effect of disinfectant type:}

No significant effects were detected for the effect of the disinfectant type on all traits under this study except that for \%early embryonic mortality $(\mathrm{P} \leq 0.05)$, Table (1). Means of the \%overall hatchability, Table (2), revealed a general trend with disinfectant type. The higher merits and consequence have been related, however, with Egg-Washer-Pro and Biosentry904, followed in most traits by Virkon-S and eventually the control group.

As shown in Table (2), early and late embryonic mortality showed low values for EggWasher-Pro disinfectant while the highest values were recorded for Virkon-S disinfectant without clear trend for the other disinfectants treatments. On the other hand, the worst values of $\%$ Omphalitis were recorded by disinfectant treatments compared to control groups. In contrast, \% abnormal chicks were low for all disinfectant treatments compared to the control group. Nevertheless, the highest value of \%pipped eggs was recorded for Biosentry-904 while the lowest value recorded by Virkon-S disinfectant (Table 2). 


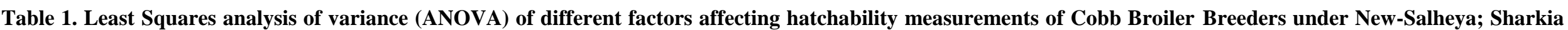
Province Situations

\begin{tabular}{|c|c|c|c|c|c|c|c|c|c|c|c|c|c|c|c|c|c|c|c|c|c|c|c|}
\hline \multirow{2}{*}{ Traits \% } & \multirow{2}{*}{ DF } & \multicolumn{2}{|c|}{$\begin{array}{l}\text { Trolley-overall- } \\
\text { hatchability }\end{array}$} & \multicolumn{2}{|c|}{$\begin{array}{l}\text { Tray hatched } \\
\text { chicks }\end{array}$} & \multicolumn{2}{|c|}{$\begin{array}{l}\text { Apparent } \\
\text { Fertility }\end{array}$} & \multicolumn{2}{|c|}{ Infertility } & \multicolumn{2}{|c|}{$\begin{array}{l}\text { Fertile } \\
\text { hatchability }\end{array}$} & \multicolumn{2}{|c|}{ Omphalitis } & \multicolumn{2}{|c|}{$\begin{array}{l}\text { Abnormal } \\
\text { chicks }\end{array}$} & \multicolumn{2}{|c|}{ Early mortality } & \multicolumn{2}{|c|}{ Late mortality } & \multicolumn{2}{|c|}{ Pipped Eggs } & \multicolumn{2}{|c|}{ Egg Losses } \\
\hline & & $\tilde{\partial} \pi$ & $\begin{array}{c}\mathrm{P} \\
\text { Value }\end{array}$ & $\begin{array}{c}\mathrm{F} \\
\text { Value }\end{array}$ & $\begin{array}{c}\mathrm{P} \\
\text { Value }\end{array}$ & $\begin{array}{c}\mathrm{F} \\
\text { Value }\end{array}$ & $\begin{array}{c}\mathrm{P} \\
\text { Value }\end{array}$ & $\begin{array}{c}\mathrm{F} \\
\text { Value }\end{array}$ & $\begin{array}{c}\mathrm{P} \\
\text { Value }\end{array}$ & $\begin{array}{c}\mathrm{F} \\
\text { Value }\end{array}$ & $\begin{array}{c}\mathrm{P} \\
\text { Value }\end{array}$ & $\begin{array}{c}\mathrm{F} \\
\text { Value }\end{array}$ & $\begin{array}{c}\mathrm{P} \\
\text { Value }\end{array}$ & $\begin{array}{c}\mathrm{F} \\
\text { Value }\end{array}$ & $\begin{array}{c}\mathrm{P} \\
\text { Value }\end{array}$ & $\begin{array}{c}\mathrm{F} \\
\text { Value }\end{array}$ & $\begin{array}{c}\mathrm{P} \\
\text { Value }\end{array}$ & $\begin{array}{c}\mathrm{F} \\
\text { Value }\end{array}$ & $\begin{array}{c}\mathrm{P} \\
\text { Value }\end{array}$ & $\begin{array}{c}\mathrm{F} \\
\text { Value }\end{array}$ & $\begin{array}{c}\mathrm{P} \\
\text { Value }\end{array}$ & $\begin{array}{c}\mathrm{F} \\
\text { Value }\end{array}$ & $\begin{array}{c}\mathrm{P} \\
\text { Value }\end{array}$ \\
\hline $\begin{array}{l}\text { Disinfectants } \\
\text { (Dis.) }\end{array}$ & 3 & 1.03 & 0.3827 & 0.61 & 0.6100 & 0.20 & 0.8981 & 0.20 & 0.8981 & 0.79 & 0.5025 & 0.40 & 0.7518 & 1.70 & 0.1670 & 3.46 & 0.0168 & 0.35 & 0.7914 & 0.49 & 0.6890 & 0.54 & 0.6583 \\
\hline Storage (St) & 5 & 10.32 & $<.0001$ & 10.73 & $<.0001$ & 7.19 & $<.0001$ & 7.19 & $<.0001$ & 6.86 & $<.0001$ & 2.73 & 0.0197 & 0.75 & 0.5879 & 2.22 & 0.0519 & 6.17 & $<.0001$ & 4.82 & 0.0003 & 0.77 & 0.5721 \\
\hline Dis X St & 15 & 0.29 & 0.9951 & 0.77 & 0.7075 & 0.89 & 0.5797 & 0.89 & 0.5797 & 0.87 & 0.6003 & 0.81 & 0.6661 & 0.77 & 0.7103 & 1.05 & 0.4033 & 0.73 & 0.7584 & 1.05 & 0.4041 & 0.61 & 0.8696 \\
\hline $\begin{array}{l}\text { Production Status } \\
\text { (P) }\end{array}$ & 1 & 44.28 & $<.0001$ & 34.42 & $<.0001$ & 12.99 & 0.0004 & 12.99 & 0.0004 & 25.59 & $<.0001$ & 0.07 & 0.7926 & 0.03 & 0.8709 & 8.68 & 0.0035 & 2.18 & 0.1408 & 23.92 & $<.0001$ & 3.91 & 0.0490 \\
\hline Dis $\mathrm{X} P$ & 3 & 0.17 & 0.9162 & 0.98 & 0.4034 & 1.40 & 0.2427 & 1.40 & 0.2427 & 0.41 & 0.7467 & 0.13 & 0.9449 & 1.70 & 0.1661 & 0.32 & 0.8124 & 2.33 & 0.0743 & 0.21 & 0.8920 & 1.95 & 0.1210 \\
\hline St X P & 1 & 24.01 & $<.0001$ & 20.95 & $<.0001$ & 10.99 & 0.0010 & 10.99 & 0.0010 & 13.60 & 0.0003 & 0.38 & 0.5397 & 5.95 & 0.0152 & 7.26 & 0.0074 & 3.84 & 0.0509 & 2.71 & 0.1010 & 0.00 & 1.0000 \\
\hline Dis $X$ St $X$ & 3 & 0.33 & 0.8042 & 0.09 & 0.9648 & 1.01 & 0.3867 & 1.01 & 0.3867 & 0.47 & 0.7033 & 0.76 & 0.5163 & 1.42 & 0.2363 & 0.94 & 0.4215 & 0.55 & 0.6457 & 1.08 & 0.3561 & 0.44 & 0.7226 \\
\hline $\begin{array}{l}\text { Season } \\
\text { (S) }\end{array}$ & 1 & 1.62 & 0.2069 & 1.69 & 0.1940 & 0.03 & 0.8521 & 0.03 & 0.8521 & 2.80 & 0.0950 & 1.77 & 0.1840 & 3.34 & 0.0686 & 0.17 & 0.6776 & 0.73 & 0.3927 & 6.87 & 0.0092 & 1.59 & 0.2085 \\
\hline Dis $\mathrm{XS}$ & 3 & 0.09 & 0.9642 & 0.29 & 0.8297 & 0.24 & 0.8699 & 0.24 & 0.8699 & 0.25 & 0.8609 & 0.60 & 0.6166 & 1.15 & 0.3282 & 0.08 & 0.9724 & 0.83 & 0.4781 & 0.07 & 0.9740 & 0.12 & 0.9475 \\
\hline St X S & 1 & 0.05 & 0.8261 & 0.40 & 0.5269 & 0.64 & 0.4235 & 0.64 & 0.4235 & 1.50 & 0.2212 & 0.73 & 0.3947 & 2.34 & 0.1268 & 0.28 & 0.5958 & 0.22 & 0.6425 & 2.68 & 0.1028 & 0.81 & 0.3687 \\
\hline Dis $X$ St $X S$ & 3 & 0.35 & 0.7911 & 0.11 & 0.9548 & 0.16 & 0.9256 & 0.16 & 0.9256 & 0.16 & 0.9264 & 0.39 & 0.7636 & 1.87 & 0.1338 & 0.64 & 0.5881 & 1.67 & 0.1743 & 0.20 & 0.8969 & 0.81 & 0.4876 \\
\hline
\end{tabular}


Effect of storage period:

Results showed that effects of storage period were significant (Table 1), on most incubation egg measurements (i.e. \% overall hatchability, \% apparent fertility, \% infertility, \%hatchability, \%late embryonic mortality and \% pipped eggs traits $(\mathrm{P} \leq 0.001 ; \mathrm{P} \leq$ 0.0001). The results in Table (3) showed that means of storage period affected the characteristics of incubation measurements under New-Salheya; Sharkia Province Situations.

Table 2. Effect of disinfectants (i.e. Biosentry-904, Virkon-S and Egg-Washer-Pro) on hatchability measurements of Cobb Broiler Breeders under New-Salheya; Sharkia Province Situations

\begin{tabular}{|c|c|c|c|c|c|c|c|c|c|}
\hline \multirow{3}{*}{ Traits\% } & \multirow{2}{*}{\multicolumn{2}{|c|}{ Control }} & \multicolumn{6}{|c|}{ Disinfectant } & \multirow{3}{*}{$\begin{array}{c}P \text { - } \\
\text { value }\end{array}$} \\
\hline & & & \multicolumn{2}{|c|}{$\begin{array}{c}\text { Biosentry- } \\
904\end{array}$} & \multicolumn{2}{|c|}{ Virkon-S } & \multicolumn{2}{|c|}{$\begin{array}{c}\text { Egg- } \\
\text { Washer-Pro }\end{array}$} & \\
\hline & Mean & SE & Mean & SE & Mean & SE & Mean & SE & \\
\hline $\begin{array}{l}\text { Trolley-overall- } \\
\text { hatchability }\end{array}$ & 87.17 & 0.42 & 87.59 & 0.53 & 87.49 & 0.51 & 87.66 & 0.50 & 0.53 \\
\hline Tray hatched chicks & 87.95 & 0.39 & 87.71 & 0.46 & 87.87 & 0.4 & 88.51 & 0.43 & 0.37 \\
\hline Apparent Fertility & 96.25 & 0.21 & 96.27 & 0.23 & 96.1 & 0.19 & 96.47 & 0.23 & 0.84 \\
\hline Infertility & 3.75 & 0.21 & 3.73 & 0.23 & 3.95 & 0.18 & 3.53 & 0.23 & 0.84 \\
\hline Fertile hatchability & 91.36 & 0.33 & 91.07 & 0.34 & 91.43 & 0.33 & 91.73 & 0.36 & 0.25 \\
\hline Omphalitis & 0.77 & 0.04 & 0.86 & 0.06 & 0.88 & 0.08 & 0.93 & 0.07 & 0.87 \\
\hline Abnormal chicks & 1.03 & 0.21 & 0.86 & 0.07 & 0.81 & 0.08 & 0.95 & 0.15 & 0.95 \\
\hline Early mortality & $2.38^{\mathrm{a}}$ & 0.15 & $2.41^{\mathrm{a}}$ & 0.14 & $2.63^{\mathrm{a}}$ & 0.16 & $2.23^{\mathrm{b}}$ & 0.14 & 0.05 \\
\hline Late mortality & 1.25 & 0.11 & 1.25 & 0.11 & 1.26 & 0.12 & 1.22 & 0.10 & 0.55 \\
\hline Pipped Eggs & 4.61 & 0.22 & 4.73 & 0.22 & 4.26 & 0.21 & 4.64 & 0.25 & 0.38 \\
\hline Egg Losses & 0.73 & 0.07 & 0.67 & 0.00 & 0.79 & 0.08 & 0.67 & 0.00 & 0.62 \\
\hline
\end{tabular}

Table 3. Effect of storage period (from one through six) on hatchability measurements of Cobb Broiler Breeders under New-Salheya; Sharkia Province Situations

\begin{tabular}{|c|c|c|c|c|c|c|c|c|c|c|c|c|c|}
\hline \multirow{3}{*}{ Traits \% } & \multicolumn{12}{|c|}{ Storage duration (days) } & \multirow{3}{*}{$\begin{array}{c}P \text { - } \\
\text { value }\end{array}$} \\
\hline & \multicolumn{2}{|c|}{ One } & \multicolumn{2}{|c|}{ Two } & \multicolumn{2}{|c|}{ Three } & \multicolumn{2}{|c|}{ Four } & \multicolumn{2}{|c|}{ Five } & \multicolumn{2}{|c|}{ Six } & \\
\hline & Mean & SE & Mean & $\mathbf{S E}$ & Mean & $\mathbf{S E}$ & Mean & SE & Mean & SE & Mean & $\mathbf{S E}$ & \\
\hline $\begin{array}{l}\text { Trolley- } \\
\text { overall- } \\
\text { hatchability }\end{array}$ & $85.18^{\mathrm{c}}$ & 0.58 & $85.84^{\mathrm{bc}}$ & 0.89 & $88.75^{\mathrm{a}}$ & 0.2 & $87.33^{\mathrm{ab}}$ & 0.29 & $85.63^{\mathrm{bc}}$ & 0.67 & $86.05^{\mathrm{ab}}$ & 0.76 & 0.0001 \\
\hline $\begin{array}{l}\text { Tray } \\
\text { hatched } \\
\text { chicks }\end{array}$ & $85.5^{\mathrm{c}}$ & 0.69 & $86.31^{b c}$ & 0.65 & $89.47^{\mathrm{a}}$ & 0.23 & $87.72^{\mathrm{ab}}$ & 0.37 & $86.11^{b c}$ & 0.81 & $86.11^{b c}$ & 1.14 & 0.0001 \\
\hline $\begin{array}{l}\text { Apparent } \\
\text { Fertility }\end{array}$ & $94.56^{\mathrm{d}}$ & 0.46 & $95.38^{\mathrm{dc}}$ & 0.31 & $96.96^{\mathrm{a}}$ & 0.12 & $96.11^{\mathrm{abc}}$ & 0.2 & $96.39^{\mathrm{ab}}$ & 0.62 & $95.61^{\mathrm{bc}}$ & 0.56 & 0.0001 \\
\hline Infertility & $5.44^{\mathrm{a}}$ & 0.46 & $4.62^{\mathrm{ab}}$ & 0.31 & $3.06^{\mathrm{d}}$ & 0.12 & $3.89^{\mathrm{bcd}}$ & 0.2 & $3.61^{\mathrm{cd}}$ & 0.62 & $4.39^{\mathrm{bc}}$ & 0.56 & 0.0001 \\
\hline $\begin{array}{l}\text { Fertile } \\
\text { hatchability }\end{array}$ & $90.43^{\mathrm{ab}}$ & 0.62 & $90.43^{\mathrm{ab}}$ & 0.48 & $92.27^{\mathrm{a}}$ & 0.22 & $91.25^{\mathrm{ab}}$ & 0.31 & $89.37^{\mathrm{b}}$ & 0.97 & $90.05^{\mathrm{b}}$ & 0.98 & 0.0001 \\
\hline Omphalitis & 0.76 & 0.10 & 0.75 & 0.04 & 0.91 & 0.06 & 0.8 & 0.05 & 1.13 & 0.14 & 0.89 & 0.14 & 0.704 \\
\hline $\begin{array}{l}\text { Abnormal } \\
\text { chicks }\end{array}$ & 0.67 & 0.00 & 0.79 & 0.07 & 1.01 & 0.11 & 0.88 & 0.11 & 0.67 & 0.00 & 0.00 & 0.00 & 0.6762 \\
\hline $\begin{array}{l}\text { Early } \\
\text { mortality }\end{array}$ & 3.67 & 0.46 & 2.43 & 0.19 & 2.20 & 0.10 & 2.59 & 0.14 & 2.56 & 0.48 & 2.28 & 0.41 & 0.1827 \\
\hline $\begin{array}{l}\text { Late } \\
\text { mortality }\end{array}$ & $0.8^{\mathrm{b}}$ & 0.13 & $1.15^{\mathrm{b}}$ & 0.09 & $1.24^{\mathrm{b}}$ & 0.08 & $1.17^{\mathrm{b}}$ & 0.11 & $1.2^{\mathrm{b}}$ & 0.17 & $2.40^{\mathrm{a}}$ & 0.27 & 0.0001 \\
\hline $\begin{array}{l}\text { Pipped } \\
\text { Eggs }\end{array}$ & $4.39^{\mathrm{bc}}$ & 0.36 & $5.29^{\mathrm{ab}}$ & 0.29 & $4.11^{\mathrm{c}}$ & 0.16 & $4.6^{\mathrm{abc}}$ & 0.21 & $5.67^{\mathrm{a}}$ & 0.7 & $4.78^{\mathrm{abc}}$ & 0.5 & 0.0001 \\
\hline $\begin{array}{l}\text { Egg } \\
\text { Losses }\end{array}$ & 0.67 & 0.00 & 0.71 & 0.05 & 0.71 & 0.05 & 0.78 & 0.11 & 0.00 & 0.00 & 0.00 & 0.00 & 0.9049 \\
\hline
\end{tabular}


However, no significant effects were detected for storage period on the remainder traits. The results proved superiority of the three and four days of storage on hatched chicks compared to other groups, followed without clear preference trend by two, five and six days, while the lowest values was recorded by one day storage period, respectively. On the other hand, the values of \% early embryonic mortality were reduced while the values of late embryonic mortality increased with progress of storage days. All these results revealed generally that most hatchery measurements can be improved considerably by storing fertile eggs for two to four days before setting eggs in incubators

Effect of egg production status (before and atpeak):

As shown in Table (1), most the characteristics of incubation measurements varied significantly with flock production status (peak effect). The recorded values for most studied traits (i.e. \%overall hatchability, \% hatchability, $\%$ fertility and $\%$ infertility, $\%$ early embryonic mortality and \%pipped eggs) varied significantly $(\mathrm{P} \leq 0.01, \mathrm{P} \leq 0.001$ or $\mathrm{P} \leq 0.001)$ with flock production status (peak effect- i.e. at middle age-table 4). In contrast, the effect of egg production before peak (young age-table 4) proved best results for the remainder traits (i.e. \% Omphalitis, \% Abnormal chicks, \%late embryonic mortality and \% egg losses).

\section{Effect of season:}

Only \%pipped eggs trait was significantly $(\mathrm{P} \leq 0.01$ - table 1$)$ varied with season effect in favor of winter season (Table 5), while the remainder of incubation measurements characteristics were insignificantly varied.

Table 4. Effect of flock physiological status (i.e. Before peak and At peak) on hatchability measurements of Cobb Broiler Breeders under New-Salheya; Sharkia Province Situations

\begin{tabular}{lccccc}
\hline \multirow{2}{*}{ Traits \% } & \multicolumn{4}{c}{ Egg production } & \multirow{2}{*}{$\boldsymbol{P}$-value } \\
\cline { 2 - 4 } & \multicolumn{2}{c}{ Before peak } & \multicolumn{2}{c}{ At peak } & \\
\cline { 2 - 4 } & Mean & SE & Mean & SE & \\
\hline Trolley-overall-hatchability & $86.21^{\mathrm{b}}$ & 0.46 & $88.32^{\mathrm{a}}$ & 0.21 & 0.0001 \\
Tray hatched chicks & $86.76^{\mathrm{b}}$ & 0.4 & $88.84^{\mathrm{a}}$ & 0.21 & 0.0001 \\
Apparent Fertility & $95.81^{\mathrm{b}}$ & 0.19 & $96.59^{\mathrm{a}}$ & 0.12 & 0.0007 \\
Infertility & $4.22^{\mathrm{a}}$ & 0.19 & $3.41^{\mathrm{b}}$ & 0.12 & 0.0006 \\
Fertile hatchability & $90.53^{\mathrm{b}}$ & 0.31 & $91.98^{\mathrm{a}}$ & 0.18 & 0.0001 \\
Omphalitis & 0.76 & 0.04 & 0.92 & 0.04 & 0.8154 \\
Abnormal chicks & 0.88 & 0.09 & 0.93 & 0.08 & 0.6762 \\
Early mortality & $2.81^{\mathrm{a}}$ & 0.13 & $2.14^{\mathrm{b}}$ & 0.08 & 0.0009 \\
Late mortality & 1.04 & 0.09 & 1.35 & 0.06 & 0.2981 \\
Pipped Eggs & $5.00^{\mathrm{a}}$ & 0.2 & $4.27^{\mathrm{b}}$ & 0.13 & 0.0001 \\
Egg Losses & 0.72 & 0.03 & 0.73 & 0.07 & 0.1454 \\
\hline
\end{tabular}

Table 5. Effect of season (i.e. Spring and Winter) on hatchability measurements of Cobb Broiler Breeders under New-Salheya; Sharkia Province Situations

\begin{tabular}{lccccc}
\hline \multirow{2}{*}{ Traits \% } & \multicolumn{4}{c}{ Season } & \multirow{2}{*}{ Winter } \\
\cline { 2 - 5 } & \multicolumn{2}{c}{ Spring } & \multicolumn{2}{c}{ Malue } \\
\cline { 2 - 4 } & Mean & SE & Mean & SE & \\
\hline Trolley-overall-hatchability & 88.02 & 0.24 & 86.94 & 0.41 & 0.2096 \\
Tray hatched chicks & 88.56 & 0.24 & 87.47 & 0.34 & 0.1940 \\
Apparent Fertility & 95.54 & 0.14 & 96.01 & 0.16 & 0.8521 \\
Infertility & 3.46 & 0.14 & 3.99 & 0.16 & 0.8534 \\
Fertile hatchability & 91.72 & 0.21 & 91.07 & 0.27 & 0.0950 \\
Omphalitis & 0.46 & 0.04 & 0.31 & 0.03 & 0.1840 \\
Abnormal chicks & 0.09 & 0.02 & 0.25 & 0.04 & 0.0686 \\
Early mortality & 2.10 & 0.10 & 2.53 & 0.12 & 0.6776 \\
Late mortality & 0.91 & 0.07 & 0.59 & 0.06 & 0.3927 \\
Pipped Eggs & $4.40 \mathrm{~b}$ & 0.15 & $4.70 \mathrm{a}$ & 0.17 & 0.0092 \\
Egg Losses & 0.02 & 0.01 & 0.13 & 0.02 & 0.2085 \\
\hline
\end{tabular}

\section{DISSCUTION}

The results of this study demonstrate superiority of all disinfectants in improving most of hatching eggs traits compared with control treatment. The utmost usefulness of most traits was recorded by the Egg-Washer-Pro
(Enzymatic) disinfectant followed by Biosentry904 (Quaternary ammonium compound) and Virkon-S (Oxidizing agent). Disinfectant selection and use are crucial to a good hatchery sanitation program (Wineland and Carmen, 2007). Consequently, improved hatchability may be as a direct result of decreased microbial contamination of the egg. Egg-Washer-Pro is 
considered a safe disinfectant since it includes only digestive enzymes capable of digesting the organic matter found on the surface of egg shell and depriving the microorganism from the media it needs during the process of penetration. Therefore, it has dual mode of action of good cleaning and microbial stabilizing disinfectant activity. This is allowing for a long enough contact time and thus saving on water consumption, energy costs and cleaning time with exceptional grease-cutting properties, superior detergency, removal of dried on soiling and staining and eventually removes calcium deposits, whilst safer for the operator, is a green agricultural and food processing disinfectant designed to address concerns about food security and traceability for hatcheries with low corrosion formula since the enzymes were of high specificity.

The results showed that Egg-Washer-Pro treatment had no detrimental impact on the cuticle of the egg or the developing embryo. From the above reasons, it can be emphasized the importance of the choice and use of disinfectants to improve the qualities of hatching chicks (Zeweil et al., 2015).

In addition, Egg-Washer-Pro improves hatchability and reduces internal contamination of eggs. Although hatching egg disinfection is often helpful to reduce contamination on egg shell surface, it is not the only solution and special attention should be taken to produce microbial free egg that does not need to be disinfected. Less microbial contamination could also aid in the production of cleaner and healthier chicks (Harry, 1957). It is obvious that the results of disinfection are greatly influenced by the timing of treatment and the type of disinfectant.

A major cause of increased first week chick mortality is \%Omphalitis, or navel yolk sac infection, which is a problem related to hatchery sanitation. Early mortality usually begins within 24 hours of the hatch and peaks by $5-7$ days. For \% Omphalitis to occur, causative bacteria such as Staphylococcus, Streptococcus and Proteus must be present. The likelihood of $\%$ Omphalitis developing is much higher in a batch of eggs that includes more dirty eggs, or if the hatcher components and equipments are not thoroughly cleaned and disinfected (Mayes and Takeballi, 1983). Also, there is a relationship between airborne microbial pathogens and bacterial contamination of eggs and hatching chicks (Magwood, 1962; 1964). Bacterial contamination of yolk sacs can alter nutrients found in the yolk, rendering them unavailable for absorption by the yolk sac membranes (Sander and Wilson, 1999) and adversely affect passive antibody absorption (Sander et al., 1998). Furthermore, nutrients in the yolk combined with the body temperature of the chick will produce rapid bacterial multiplication. Maternally derived immunity will not offer sufficient protection against this invasive challenge while the chick's own immune system is still immature. In the present study, used disinfectants slightly increased \% Omphalitis and pipped of the hatching eggs. This could not probably be resulted from the harmful effect of disinfectants, since control treatment had higher \%early embryonic mortality and abnormal chicks and lower hatchability than treated eggs. However spraying hatching eggs with Egg-Washer-Pro can be an effective way to reduce the number of microorganisms on the hatching eggs.

The results of this study showed that storage of eggs for three or four days proved superiority for most hatchability traits. The lowest values of the traits were recorded for eggs stored for one day and non clear trend observed for rest of days of stored eggs. These results are in agreement with most of the previous studies which reported that 3 days or and even till 5 days of storage acquired better hatchability measurements compared with longer storage days (Petek and Dikmen, 2006; Reijrink et al., 2009; Egbeyale et al., 2013; Khan et al., 2013 and 2014). An epidemiological study of Dutch hatchery data (Yassin et al., 2008) showed that, on average, each extra day of storage at the hatchery before the seventh day reduced hatchability by $0.2 \%$, rising to $0.5 \%$ after the seventh day. Indeed, storage from seven days or more alters the characteristics of albumen, reduces incubation yield, increases incubation period and can damage embryonic development. This decrease in viability of the embryo may be caused by changes in the embryo or by changes in certain physical aspects of the egg, namely albumen $\mathrm{pH}$ which causes movement of nutrients from the albumen to the blastoderm and may reduce resistance to gaseous diffusion (Lapao et al., 1999). Egbeyale et al. (2013) reported that excessive storage duration makes unsuitable environment for embryo survival through evidence of necrosis and regressive changes in the blastoderm and hence fail to develop. Furthermore, extended periods of egg storage cause degradation of albumen which in turn, causes the movement of the blastoderm into close proximity to the eggshell which sequentially leading to the early embryonic mortality (Brake et al., 1993). Khan et al., (2014) suggested that increase of embryonic mortality could be due to water loss and albumen degradation during storage.

Results in Table (3) revealed no significant effect for storage period on early mortality, Omphalitis, egg losses and abnormal chicks traits under consideration. The worst values for early mortality, Omphalitis, abnormal chicks and egg losses were detected for eggs stored for 5, 3, and one day(s), respectively. The results showed 
clear trend of effect of storage period on \%early embryonic mortality. Egbeyale et al. (2013) showed that the higher embryonic mortality could be as a result of cell death during preincubation storage period. Assuming chicks are brooded properly, high early mortality is usually related to a hatchery or breeder flock problems. During the cooling process the egg contents begin to shrink producing negative pressure. This is one of the more opportune times for bacteria on the shell surface to penetrate the eggshell. On the other hand, Christensen et al. (2003) observed that optimal hatching results and chick quality can be achieved if eggs are set after an initial adaptation period of about one to two day(s). This allows carbon dioxide to be released from the egg, which increases albumen $\mathrm{pH}$, and improves carbohydrate utilization, by the embryos. Also, Asmundson and MacLlriath (1948) reported that eggs stored for a few days presented higher hatchability than those set in an incubator immediately after lay. However, the hatching performance would most certainly be improved by reducing the length of the storage period.

In the present study, most incubation egg traits varied significantly with flock production status (peak) effect (Table 4). The best recorded values for trolley-overall-hatchability, \%hatched chicks, \% fertile and infertility \%, \%early embryonic mortality and \%pipped eggs were for at-peak egg production. Similar results have been observed previously by Alsobayel (1992), Pedroso et al. (2005) and Alsobayel et al. (2013) who reported highly significant $(\mathrm{P}<0.05)$ difference of the effects of breeders age on fertility rate and hatchability percentage. The highest fertility rate among the age of hen groups was found in middle aged hens followed by youngest group of hens and the fertility decreased with the increase in hen's age (Othman et al., 2014). Islam et al., (2008) showed that, with groups of breeder hens, the highest hatchability was found in 41 to 60 weeks and lowest in 28 to 40 weeks. There may be a distinct explanation for the higher fertility and hatchability $\%$ of eggs from peak production flocks. Hens at peak production are of optimum physiological reproductive age and consequently that affects their ability to fertilize their egg upon mating. Also, they produce good quality eggs and embryos that grow at an optimum rate, which may result in high hatchability rate (Tona et al., 2004). Furthermore, eggs from peak production flocks hatch earlier than eggs from younger or older flocks. Consistence with this explanation, our results showed that the percentages of early embryonic mortality and pipped eggs were highly significant $(\mathrm{P}<0.0001)$ in eggs from 28 to 34 weeks old (before peak). Suarez et al., (1997), Applegate (2002) and Dudusola (2013) reported that eggs from young breeder hens have small yolk and consequently less yolk lipid available for the embryo, resulting in greater embryo mortalities.

In present results, the effect of egg production before peak proved best values for $\%$ Omphalitis, \% abnormal chicks, late embryonic mortality and egg losses compared to at flock production status (peak effect) with non significant differences. However, eggs from young flocks are more susceptible to desiccation than eggs from older flocks (Pedroso et al., 2005 and Ojedapo, 2013). During the second half of the incubation period the eggs loose moisture at a slightly higher rate than during the first half, because during the second half the embryos are producing metabolic heat which slightly raises the water vapor partial pressure. Also, shell conductance is increased slightly during the second half of incubation due to calcium absorption by the developing embryo from the shell which results in shell thinning.

The nonappearance of a significant season effect on most of the traits under consideration may probably be due to that the broiler breeder flocks are reared under partially automated close confinement housing system. The best value of hatchability percentage was observed in winter (78.6) followed by monsoon (76.7) and summer (75.8) (Islam et al., 2008). Jesuyon and Salako (2013) showed that late wet season was most favorable for hatching activities in both Bovan Nera and ISA Brown parent stock compared with the remainder seasons. However, our results showed a tendency of most characteristics of incubation measurements to be superior during spring compared with winter season. In this respect, Farooq et al. (2003) showed that spring season proved the reveal better value of hatchability of chicken eggs $(78.0 \%)$, compared with summer $(46.5 \%)$. The best values of fertility, hatchability of total set and fertile eggs of duck were obtained in spring, winter, autumn compared with summer season, respectively (Awad, 2013). Nevertheless, fertility and rate of hatchability of eggs produced in summer and early spring was exceptionally low (Das and Ail 1999). On the other hand, Babiker and Musharaf (2008) reported an increase of mean hatchability of total eggs in summer compared with winter in Bovans-PS layers under the hot weather of Sudan. The higher hatchability during spring season in the present study could be attributed to the favorable environment for egg storage and the decline in hatchability performance in winter may be attributed to pre-incubation declined development and embryos weakening before the eggs were received at the hatchery, in a manner resembling that when eggs were not stored enough, before incubation. The differences between studies may be due to contrastive environmental conditions from one country to another or from one year to another. Generally, 
and apart from genetic factors, egg quality is influenced greatly by non-genetic factors such as season, environmental situations and feed intake (Oluyemi and Roberts, 2000).

\section{Conclusion:}

Hatchability percentages can be improved by storing broiler breeder eggs for two to four days before setting in incubators. Hatchability measurements improved considerably with flock production status (juvenile vs. full- grownup), but not with the season of the year. Hatchery should put a price penalization/correction on the grade of eggs produced from juvenile flocks to compensate for such reduced hatchability during their early production.

\section{REFERENCES}

Alsobayel, A.A., M.A. Almarshade, M.A. Albadry, 2013. Effect of breed, age and storage period on egg weight, egg weight loss and chick weight of commercial broiler breeders raised in Saudi Arabia. J. Saudi Agri. Sci., 12: 53-57.

Alsobayel, A.A., 1992. Effect of protein rearing diet and age on fertility and hatchability parameters of Saudi Arabian Baladi chickens. J king Saudi Univ., 4: 47-54.

Applegate, T.J., 2002. Reproductive maturity of turkey hens: egg composition, embryonic growth and hatchling transition. Poult. Avian Biol. Rev., 13: 31-41.

Asmundson, V.S. and J.J. MacLlriath, 1948. Preincubation tests with turkey eggs. Poult. Sci., 27: 394-401

Awad, A.L., 2013. Field studay on hatching traits of duck eggs under Egyptain environmental conditions. Egypt Poult. Sci., 33 (4): 849-863.

Babiker, J.M.S. and Z.N.A. Musharaf, 2008. The effect of season on hatchability and fertility of egg-type parent stock (Bovans) in Sudan. Res. J. Poult. Sci., 2 (1): 5-8.

Brake, J. and B.W. Sheldon, 1990. Effect of a quaternary ammonium sanitizer for hatching eggs on their contamination, permeability, water loss and hatchability. Poult. Sci., 69: 517-525.

Brake, J., T.J. Walsh and S.V. Vick, 1993. Hatchability of broiler eggs as influenced by storage and internal quality. Zootech. Int., 16: $30-41$.

Cason, J.A., N.A. Cox, and J.S. Bailey, 1994. Transmission of Salmonella typhimurium during hatching of broiler chicks. Avian Dis., 38: 583-588.

Chima, I.U., I.C. Unamba,-Opara, C.C. Ugwu, A.C. Udebuani, C.G. Okoli, M.N. Opara, M.C. Uchegbu and I.C. Okoli, 2012. Biosecurity and disinfection controls of poulrty microbial pathogen infections in Nigeria. J. Poult. Res., 2 (1): 5-17.

Christensen, V.L., J.L. Grimes, M.J. Wineland and G.S. Davis, 2003. Accelerating embryonic growth during incubation following prolonged egg storage II. embryonic growth and metabolism. Poult. Sci., 82: 1869-1878.

Cox, N.A, L.J. Richardson, R.J. Buhr, M.T. Musgrove, M.E. Berrang and W. Bright, 2007. Bactericidal effect of several chemicals on hatching eggs incubated with salmonella serovar typhimurium. J. Appl. Poult. Res., 16: 623-627.

Cox, N.A. and J.S. Bailey, 1991. Effect of chemical treatments to eliminate Salmonella on hatching eggs. Poult. Sci., 70 (Suppl. 1): 154

Das, G.B. and M.L. Ali, 1999. Raising layer chicken over fish ponds in integrated poultryfish farming system in rural areas. Bang. J. Anim. Sci., 28: 121-128.

Dudusola, I.O., 2013. The effect of parental age and egg weight on fertility, hatchability and day-old chick weight of Japanese quail (Cortunix cortunix japonica). Stand. Res. J. Agric. Sci., 1 (2): 13-16.

Egbeyale, L.T., M.K. Bosa, O.M. Sogunle and O.O. Adeleye, 2013. Effect of pre-incubation storage periods on weight loss, embryonic development, and hatchability of pullet eggs. Pacific J. Sci. Technol., 14 (2): 416-424.

Farooq, M., K. Javed, F.R. Durrani, K. Irfanullah and N. Chand, 2003. Hatching performance of backyard hens in Peshawar, Pakistan. Livestock Res. Rural Devel., 15.

Fueng-Lin, W.O, J.B. Carey, S.C. Ricke and S. Dha, 1996. Peroxidase catalyzed chemical dip, Egg shell surface contamination, and hatching. J. Appl. Poult. Res., 5: 6-13.

Gehan, M.Z., W. Anwer, H.M. Amer, I.M. ELSabagh and E. M. Badawy, 2009. Efficacy comparisons of disinfectants used the commercial poultry farms. Int. J. Poult. Sci., 8 (3): 237-241.

Gheith, S.H., A.M. Mustafa and M.A. Hamouda, 2005. Studies on the efficacy Biosentry sanitizer on contamination and hatchability of hatching eggs. Zag. Vet., 115: (3) 33.

Harry, E.G., 1957. The effect on embryonic and chick mortality of yolk contaminated with bacteria from the hen. Vet. Rec., 69: 14331439.

Islam, S.S., M.B. Hossain and M.K.A. Khan, 2008. Effect of genotype, age and season on hatchability of egg. Bang. J. Anim. Sci., 37 (1): 17-22

Jesuyon, O.M.A. and A.E. Salako, 2013. Effect of seasons on the reproductive performance of bovan Nera and Isa Brown parent-stock chickens in a hot humid environment. Int. J. Anim. Veter. Adv., 5(6): 212-215. 
Khan, J.A., S.H. Khan, A. Bukhsh and A. Muhammad, 2014. The effect of storage time on egg quality and hatchability characteristics of Rhode Island Red (RIR) hens. Veter. Arhiv., 84 (3): 291-303.

Khan, M.J.A., S. Khan, A. Bukhsh, I. Abbass and M. Javed, 2013. Effect of different storage period on egg weight, internal egg quality and hatchability characteristics of Fayumi eggs .Poult. Res. Inst., 12: 2.

Kingori, A.M., 2011. Review of the factors that influence egg fertility and hatchability in poultry. Int. J. Poult. Sci., 10 (6): 483-492.

Lapao, C.O, L.T. Gama and M. Soares 1999. Effects of broiler breeder age and length of egg storage on albumen characteristics and hatchability. Poult. Sci., 78: 640-645.

Magwood, S.E., 1962. Evaluation of a method for determining microbial counts of hatcher fluff. Avian Dis., 6: 24-32.

Magwood, S.E., 1964. Studies in hatchery sanitation III. The effect of air-borne bacterial populations on contamination of egg and embryo surfaces. Poult. Sci., 43: 15671572.

Mauldin, J.M., and J.L Wilson, 1988. Watch egg weight during incubation. Poult. Digest., 47: 342-344.

Mayes, F.J. and M.A. Takeballi, 1983. Microbial contamination of the hen's egg: A review. J. Food Prot., 46: 1092-1098.

Moreki, J.C. and N. Mack, 2013. Effect of storage time and egg position on hatchability of guinea fowl eggs. J. Anim. Sci. Adv., 3 (5): 256-260.

North, B., 1984. Commercial chicken production manual. Third Edition. Van Nostr and Reinhold, New York.

Ojedapo, L.O., 2013. Effect of age and season on egg quality traits of Isa Brown layer strain reared in derived savanna zone of Nigeria. Transnational J. Sci. Technol., 3 (7): 48-60.

Oluyemi, J.A. and F.A. Roberts, 2000. Poultry production in warm wet climate. Macmillan Publishers, Ltd., London, UK.

Othman, R.A., M.R. Amin and S. Rahman, 2014. Effect of egg size, age of hen and storage period on fertility, hatchability, embryo mortality and chick malformations in eggs of Japanese quail (Coturnix coturnix japonica). J. Agric. Veter. Sci., 7(1): 101-106.

Pedroso, A.A., M.A. Andrade, M.B. Caf, N.S. Leandro, J.M. Fernando and J.H. Stringhini, 2005. Fertility and hatchability of eggs laid in the pullet-to-breeder transition period and in the initial production period. Anim. Repro. Sci., 90: 355-364.

Petek, M. and S. Dikmen, 2006. The effects of prestorage incubation and length of storage of broiler breeder eggs on hatchability and subsequent growth performance of progeny. Czech J. Anim. Sci., 5: 73-77.
Reijrink, I.A.M., R. Me ijerhof, B. Kemp, E.A.M. Graat and H. VanDen Brand, 2009. Influence of prestorage incubation on embryonic development, hatchability, and chick quality. Poult. Sci., 88: 2649-2660.

Romao, J.M., T.G.V. Moraes, R.S.C. Teixeira, W.M. Cardoso and C. C. Buxade, 2008. Effect of egg storage length on hatchability and weight loss in incubation of egg and meat type Japanese quails. Rev. Bras. Cienc. Avic., 10: 3

Russell, A.D., W.B. Hugo and G.A.J. Ayliffe, 1992. Principles and practice of disinfection, preservation, and sterilization. $2^{\text {nd }}$ ed. Blackwell Publishing, Oxford, UK.

Samberg, Y. and M. Meroz, 1995. Application of disinfectants in poultry hatcheries. Rev. Sci. tech. Off. int. Epiz., 14 (2): 365-380

Sander, J.E. and J.L. Wilson, 1999. Effect of hydrogen peroxide disinfection during incubation of chicken eggs on microbial levels and productivity. Avian Dis., 43: 227233.

Sander, J.E., E.M. Willinghan, J.L. Wilson and S.G. Thayer, 1998. The effect of inoculating Enterococcus faecalisin to the yolk sac on chick quality and maternal antibody absorption. Avian Dis., 42:359-363.

SAS., 2003. Statistical Analysis System, version 9.3, SAS Institute Incorporation Cary, NC, USA.

Scott, T.A. and C. Swetnam, 1993a. Screening sanitizing agents and methods of application for hatching eggs. I. Environment and user friendliness. J. Appl. Poult. Res., 2: 1-6.

Scott, T.A. and C. Swetnam, 1993b. Screening sanitizing agents and methods of application for hatching eggs. 11. Effectiveness against a"cocktail" of microorganisms on the egg shell. J. Appl. Poult. Res., 2: 7-11.

Sheldon, B.W. and J. Brake, 1991. Hydrogen peroxide as an alternative hatching egg disinfectant. Poult. Sci., 70: 1092-1098.

Suarez, M.E., H.R. Wilson, F.B. Mather, C.J. Wilcox and B.N. Mcpherson, 1997. Effect of strain and age of the broiler breeder female on incubation time and chick weight. Poult. Sci., 76: 1029-1036.

Tona, K.O., B. Onagbesan, De Ketelaere, E. Decuypere and V. Bruggeman, 2004. Effects of age of broiler breeders and egg storage on egg quality, hatchability, chick quality, chick weight, and chick post hatch growth to fortytwo days .J. Appl. Poult. Res., 13: 10-18.

Winel and M. and C. Carmen, 2007. Spray sanitizing hatching eggs. North Carolina State University: http://www.ces.ncsu.edu/depts/poulsci/

Yassin, H., A.G.J. Velthuis, M. Boerjan, J. van Riel and R.B.M. Huirne, 2008. Field study on broiler eggs hatchability. Poult. Sci., 87: 2408-2417. 
Zeweil, H.S., R.E. Rizk, G.A.H. Bekhet and A.R.M. Mona, 2015. Comparing of the effectiveness of egg disinfectants against bacteria and mitoticindices of developing chick embryos. J. Basic\&Appl. Zool., 70:115 .

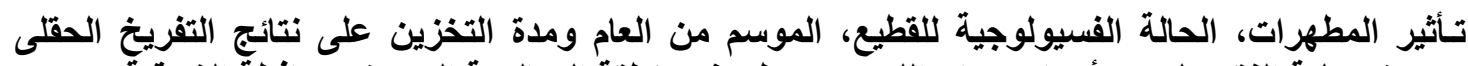

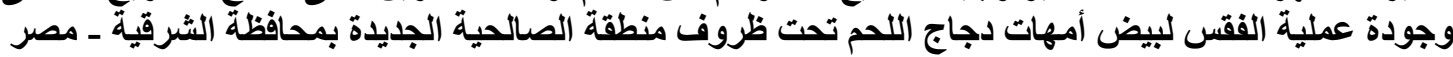

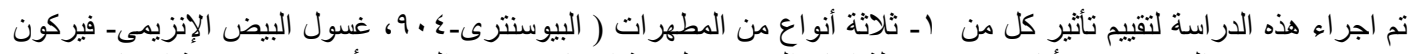

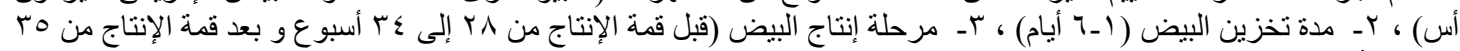

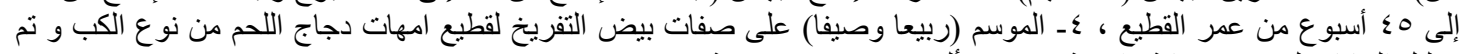

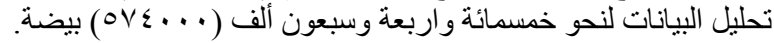

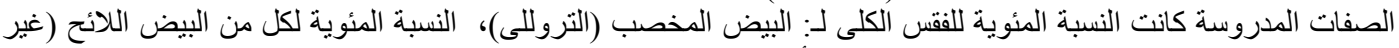

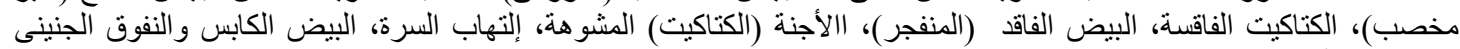
المبكر و المتأخر لكل صينية (كوحدة تجريبية).

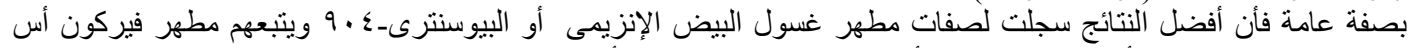

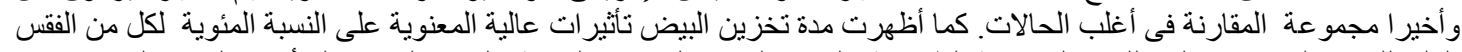

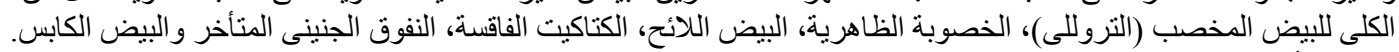

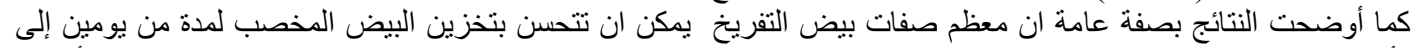

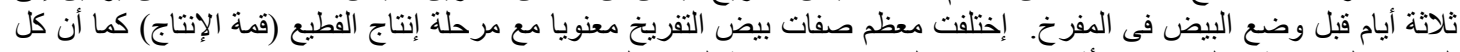
الصفات الددروسة إختلفت بدون تأثير معنوى مع الموسم ماعدا صفة البيض الكابس. 